10.15290/cnisk.2019.02.07.02

DR HAB. MAGDALENA GRABOWSKA

https://orcid.org/0000-0002-0896-1346

Instytut Filozofi i Socjologii PAN

\title{
Transformacja ruchów kobiecych w Polsce (1945-1956)
}

\section{Streszczenie}

Jak zmieniał się ruch kobiecy w Polsce po 1945 r.? Niniejszy artykuł stanowi próbę odpowiedzi na pytania, jakie były cele ruchu kobiecego po II wojnie światowej oraz jakie strategie wybierały działaczki kobiece, wdrażając plany emancypacyjne. Argumentuję w nim, że „produktywizacja” kobiet, upolitycznienie ruchu kobiecego, a także jego umasowienie stanowiły główne osie działania ruchu kobiecego po 1945 r. Jednocześnie cele i strategie emancypacyjne realizowane w powojennej Polsce były zbieżne zarówno $z$ działaniami podejmowanymi na Zachodzie, jak i tymi w ramach instytucji międzynarodowych (np. Światowej Demokratycznej Federacji Kobiet).

Słowa kluczowe: socjalistyczna emancypacja, ruch kobiecy, Liga Kobiet

\section{TRANSFORMATION OF WOMEN'S MOVEMENTS IN POLAND (1945-1956)}

\begin{abstract}
In what way did women's movement in Poland develop after 1945? This article is an attempt to answer the question on what the goals of women's movement after World War II were, and what strategies were chosen to fulfill emancipatory agendas after 1945. I argue that women's productiv-
\end{abstract}


isition, along with politicisation of women's movement and an attempt to build a massive women's organisation were the main axes of the women's movement policy after 1945 . These goals and strategies were coherent with activities carried in the West and by international organisations (Women's International Democratic Federation).

Keywords: socialist emancipation, women's movement, League of Women

\section{Wstęp}

Współczesne badania powojennej historii społecznej wskazuja, że sposób definiowania sprawczości (ang. agency) jako emanacji z wolnej woli autonomicznej jednostki ogranicza znacząco możliwości rozważenia zakresu aktywnej podmiotowości w systemach autorytarnych, w tym sprawczości kobiet w Europie Wschodniej i Związu Radzieckim po 1945 r. ${ }^{1}$ Badaczki i badacze sugeruja, że użycie bardziej zniuansowanego podejścia do sprawczości jako głęboko osadzonej w kontekście społeczno-kulturowym jest warunkiem początkowym debaty na temat zakresu i autonomii działań na rzecz emancypacji w Polsce po 1945 r. Prowadzone dziś badania powojnia podważaja jednocześnie znaturalizowane i znormalizowane przede wszystkim jako opozycyjne wobec PRL narracje historyczne, które odbierają legitymizację działaniom emancypacyjnym kobiet po II wojnie światowej i kwestionuja sprawczość osób i grup zaangażowanych $\mathrm{w}$ te działania. Wskazuja, że krytyczna analiza strategii emancypacyjnych po 1945 r. powinna być jednym z punktów wyjścia współczesnych debat na temat tożsamości i kondycji ruchów emancypacyjnych ${ }^{2}$.

W poniższym artykule stawiam tezę, że zarówno wschodnioeuropejskie, jak i zachodnie powojenne progresywne ruchy na rzecz równości kobiet stanowią ważne ogniwo w historii ruchu kobiecego, tak na poziomie lokalnym, jak i międzynarodowym. Analiza materiałów archiwal-

\footnotetext{
1 Francisca de Haan, „Ten Years After. Communism and Feminism Revisited”, Aspasia. The International Yearbook of Central, Eastern, and Southeastern European Women's and Gender History, z. 10, 2016, 102-168; Kristen Ghodsee, Red Hangover. Legacies of Twentieth-Century Communism, (Durham, New York : Duke University Press, 2017); Agnieszka Mrozik, „Wywołać z milczenia. Historia kobiet w PRL-u - kobiety w historii PRL-u”, Teksty Drugie: teoria literatury, krytyka, interpretacja, t. 4, z. 130, 2011, 112-119.

2 Francisca de Haan, „Ten Years After”.
} 
nych, w tym dokumentów Wydziału Kobiecego Polskiej Partii Robotniczej [PPR] oraz Światowej Demokratycznej Federacji Kobiet [ŚDFK], a także analizy artykułów opublikowanych w wydawanym w latach 1947-1949 czasopiśmie „Kobieta” wskazuja, że ruch kobiecy w powojennej Polsce był aktywny zarówno w sferze politycznej, jak i społecznej, na poziomie krajowym i międzynarodowym. Centrum jego działań stanowiły kwestie zatrudnienia kobiet, umasowienia ruchu kobiecego, uspołecznienia prac domowych oraz upaństwowienia opieki nad dziećmi. Jednocześnie działaczki na rzecz równości kobiet w Polsce kładły nacisk na współpracę międzynarodowa - wymiana doświadczeń i wiedzy na temat sytuacji kobiet $\mathrm{w}$ innych częściach świata była jednym $\mathrm{z}$ kluczowych punktów programu progresywnych ruchów kobiecych. Program emancypacji kobiet wdrażany w Polsce był zbieżny $z$ postulatami artykułowanymi przez instytucje międzynarodowe (takie jak ŚDFK), a także $z$ programami organizacji aktywnych w krajach zachodnich (np. Amerykański Kongres Kobiet). Transformacja, która miała miejsce na przełomie lat 40. i 50. XX w., znacząco zmieniła oblicze ruchu kobiecego w Polsce. Przemiany polityczne, które zaszły pod koniec pierwszej dekady powojnia, doprowadziły do odpolitycznienia postulatów ruchu kobiecego oraz przekształcenia jego strategii działania, odejścia od radykalnych propozycji zmian społecznych w stronę „praktycznego aktywizmu”, którego podstawą było umożliwienie kobietom łączenia pracy zawodowej $z$ tradycyjnymi rolami $\mathrm{w}$ rodzinie.

Zmiany wprowadzane po wojnie bazowały w dużej mierze na istniejacym od $1918 \mathrm{r}$. prawie wyborczym kobiet, ustawodawstwie z $1924 \mathrm{r}$. chroniącym kobiety w ciąży i stanowiącym listę zawodów zakazanych oraz prawie z 1932 r. do legalnej aborcji w przypadku zagrożenia życia, gwałtu i kazirodztwa. Przepisy dotyczace równości kobiet ustanawiane po 1945 r. miały charakter i cel podobne do radzieckich; były częścia planu walki o pozyskanie „kobiecych mas” dla projektu komunistycznego przez wprowadzenie regulacji prawnych dotyczących równości kobiet na rynku pracy i w prawie cywilnym. Już w lipcu 1945 r. nowe polskie władze wprowadziły świeckie małżeństwo (Prawo o aktach stanu

3 Basia Nowak, "Where do you think I learned how to style my own hair?" Gender and Everyday Lives of Women Activists in Poland's League of Women", w: Shana Penn, Jill Massino (red.), Gender Politics and Everyday Life in State Socialist Eastern and Central Europe, (New York : Palgrave Macmillan, 2009), 45-58. 
cywilnego, wrzesień 1945) i prawną równość płci. W 1946 r. stworzono Wydział Kobiecy PPR, który stał się centralnym ośrodkiem walki o „kobiece masy” i upolitycznienie kwestii równości. Jego kierowniczka została Edwarda Orłowska, przed wojna działaczka Zwiąku Młodzieży Komunistycznej, a także Komunistycznej Partii Zachodniej Białorusi, która od 1944 r. budowała lokalne struktury partii w Białymstoku, a w okresie powojennym również lokalne struktury Ligi Kobiet w tym mieście. W działającej od 1919 r. Sekcji Kobiet PPS liderka była Dorota Kłuszyńska (od 1919 r.), a w powstałej w 1946 r. Centralnej Radzie Kobiet PPS Eugenia Pragierowa, od 1948 r. wiceprzewodniczaca Ligi Kobiet. W nowych władzach sekcji zasiadly aktywne od przedwojnia Dorota Kłuszyńska i Zofia Wasilkowska. W 1948 r. powstała Polska Zjednoczona Partia Robotnicza [PZPR], a w jej ramach utworzono Wydział Kobiecy, w którym aktywne były zarówno działaczki byłej PPR, jak i Polskiej Partii Socjalistycznej [PPS]. W spotkaniach aktywu kobiecego brały też udział przedstawicielki Ligi Kobiet (będąc w zdecydowanej większości członkiniami jednej z partii).

W okresie tużpowojennym zmieniał się radykalnie sposób funkcjonowania organizacji kobiecych w Polsce. Celem Społeczno-Obywatelskiej Ligi Kobiet [SOLK], która powstała w lipcu 1945 r. (i nawiązywała do tradycji organizacji z 1913 r.), była obrona praw kobiet, włączenie ich w odbudowę Polski oraz walka $z$ faszyzmem ${ }^{4}$. SOLK działała w modelu, który dziś nazwalibyśmy „parasolowym”, dążyła do bycia jedyna przedstawicielką kobiet na terenie Polski. Powoływała się jednocześnie na ideę jedności pomiędzy kobietami, niezależnie od wykształcenia, pochodzenia czy wyznawanych poglądów politycznych i religijnych. W pierwszym zarządzie znalazły się działaczki partyjne, członkinie PPR (Irena Płotnicka, Felicja Fornalska, Maria Turlejska i Izolda Kowalska), PPS (Eugenia Pragierowa, Regina Fleszerowa), Stronnictwa Ludowego [SL] (Stanisława Garncarczyk) oraz Stronnictwa Demokratycznego (Maria Jaszczukowa). Bezpartyjna pozostała Irena Sztachelska, przewodnicząca zarządu SOLK (wiceprzewodniczaca zarząu została Stanisława Garncarczyk, a sekre-

\footnotetext{
4 Anna Nowakowska-Wierzchoś, "Związałyśmy się z siłami demokratycznymi w Polsce” - program polityczny i wizja roli kobiet w "nowej Polsce» Zwiazku Kobiet Polskich im. Marii Konopnickiej we Francji 1944-1950", w: Ewa Chabros, Agnieszka Klarman (red.), Kobiety „na zakręcie” 1933-1989, (Wrocław : Instytut Pamięci Narodowej, 2014), 220-251.
} 
tarz generalną Izolda Kowalska). SOLK, a potem LK były organizacjami członkowskimi ŚSFK ${ }^{5}$.

Prasa kobieca była ważnym propagandowym i informacyjnym narzędziem promowania powojennej wizji emancypacji. W latach 19451947 SOLK wydawała dziesięć tytułów prasy kobiecej, w tym magazyn „Kobieta”, którego redaktorka naczelną była Janina Broniewska i który był kontynuacją dwutygodnika „Kobieta Dzisiejsza” (ukazującego się od marca 1946 do października 1947), oraz biuletyn „Nasza Praca”, wydawany w okresie od 1947 do 1989 r. O ile celem „Naszej Pracy” było informowanie o całokształcie działalności organizacji - był to biuletyn skierowany do członkiń stowarzyszenia - o tyle pismo prowadzone przez Broniewska miało szerszy zakres tematyczny: podejmowało kwestie polityczne (w tym dotyczace polityki międzynarodowej), społeczne (w tym zmian prawnych po 1945 r.), nie pomijając sfery kultury, mody, urody czy spraw zwiazanych $z$ prowadzeniem gospodarstwa domowego. Wizja równouprawnienia kobiet prezentowana w „Kobiecie” była $z$ pewnościa rewolucyjna, pismo nastawione było na prezentację socjalistycznej równości kobiet jako najwartościowszej wizji emancypacji, jej rama pozostawała jednak kobiecość, która niewiele miała wspólnego $z$ funkcjonujacymi dziś wyobrażeniami na temat powojennego stylu emancypacji promującego kobietę silna, surowa, pozbawioną tradycyjnych atrybutów kobiecości, takich jak makijaż, modne suknie i dodatki. Artykuły poruszające tematykę urody, strojów i kuchni wpisywały się w tradycyjnie rozumiane role kobiece, a wyrażana poprzez oprawę graficzna stylistyka nawiazywała do przedwojnia. Kobieta na traktorze zdobiła okładkę tylko jednego $z$ kilkudziesięciu numerów „Kobiety”.

\section{„Jesteśmy wszędzie”. Umasowienie ruchu kobiecego i jego upolitycznienie}

Czołowe działaczki komunistyczne postrzegały powojenny projekt emancypacji kobiet jako wielowymiarowy i odnoszacy się do kilku ważnych kwestii. Pierwszą $z$ nich było zaangażowanie kobiet w działania

\footnotetext{
5 We wrześniu 1949 r. Społeczno-Obywatelska Liga Kobiet została przekształcona w Lige Kobiet (LK), organizację w dużej mierze zależna od partii komunistycznej. Pod tą nazwa działała ona do grudnia 1982 r., kiedy to zmieniono ją na Liga Kobiet Polskich.
} 
polityczne i społeczne, stworzenie „masowego ruchu kobiecego" ${ }^{\text {. Edwar- }}$ da Orłowska, kierowniczka Wydziału Kobiecego PPR, stawiała na budowanie struktur lokalnych i międzywydziałowych, włączajacych związki zawodowe i działajace w terenie organizacje kobiece. W czerwcu 1946 r. w następujący sposób przedstawiała cele nowego ruchu kobiecego:

Pierwsze zadanie [to] rozbudowanie i usprawnienie pracy [wojewódzkich - przyp. M.G.] wydziałów kobiecych. 3 kobiety w wydziale - to za mało, należy dopełnić do 6, w tym 2-3 etatowe. KC nie będzie ograniczać etatów, jeśli będą odpowiedni, konkretni ludzie. ... Dlatego wydział kobiecy musi być 7-osobowy: kierowniczka i 2 instruktorki, 1 towarzyszka pracujaca w ORZW zaw. (stworzyć tam z PPS wydział kobiecy), 1 towarzyszka $z$ referatu kobiecego w Związku Samopomocy Chłopskiej (stworzyć tam wraz z SL referat kobiecy), 1 towarzyszka $z$ kuratorium (która by wpływała na nauczycielstwo), 1 towarzyszka $z$ Ligi Kobiet. Następnie trzeba postawić instruktorki na powiaty, nawet na 1 powiat, gdy trzeba ${ }^{7}$.

W okresie powojennym prasa kobieca stanowiła ważne narzędzie promowania emancypacji jako procesu masowego. Przykładem może być opublikowany w „Kobiecie” artykuł pod znaczącym tytułem Jesteśmy wszędzie. Prezentował on sylwetki kobiet aktywnych w różnych dziedzinach życia: od robotnic i kobiet wiejskich po naukowczynie oraz działaczki społeczne i polityczne powojennej Polski. Wśród bohaterek artykułu znalazły się m.in.: pełniąca funkcję wiceminister pracy i opieki społecznej Eugenia Pragierowa, wiceminister oświaty Eugenia Krassowska-Jodłowska, dyrektor departamentu w Ministerstwie Oświaty Żanna Kormanowa, Emilia Robiszewska, pierwsza w Polsce przewodniczaca Powiatowej Rady Narodowej, Irena Sztachelska, lekarka i przewodnicząca Zarządu Głównego SOLK, sekretarz generalna tegoż Zarządu Głównego Izolda Kowalska, posłanka Edwarda Orłowska, Natalia Jabłońska, kierowniczka internatu, Genowefa Balcerzak, kierowniczka pralni, Zofia Tomczyk, członkini SL i posłanka, Joanna Śląsk, pracownica w Fabryce Porcelany

6 Magdalena Grabowska, Zerwana genealogia. Działalność społeczna i polityczna kobiet po 1945 r. a wspótczesny polski ruch kobiecy, (Warszawa : Wydawnictwo Naukowe Scholar, 2018), 192-203.

7 Archiwum Akt Nowych, Wydział Kobiecy PPR, sytuacja i zatrudnienie kobiet w Polsce - protokoły, sprawozdania, okólniki, instrukcje, uchwały, opracowania, korespondencja, sygn. 295/XVI, Protokół z krajowej narady aktywu kobiecego PPR, 4.06.1946 r., k. 1-14. 
w Wałbrzychu na Dolnym Śląsku, architektka Bożena Cyrkusowa oraz włókniarki Anna Glad i Maria Pyziak ${ }^{8}$.

Imponujacca galeria postaci kobiecych przedstawionych $\mathrm{w}$ czasopiśmie pełniła $z$ pewnościa funkcję propagandowa - informowała, że kobiety ze wszystkich klas i zawodów wspierają nowy system społeczny i polityczny, opowiadaja się za nową władza, która w zamian oferuje im dostęp do wykształcenia, kariery zawodowej oraz awans w sferze polityki. Zamieszczona w „Kobiecie” rozkładówka była jednocześnie zachętą dla czytelniczek zarówno do pracy zawodowej, jak i do zaangażowania się w działalność społeczna i polityczna. Sugerowała, że działania na rzecz równości maja charakter zintegrowany i powszechny - dotyczą wszystkich dziedzin życia zawodowego, społecznego, politycznego i kulturalnego, i sa otwarte na wszystkie kobiety, niezależnie od ich pochodzenia społecznego. Prezentowana galeria potwierdzać więc miała postępowy charakter realizowanej w okresie tużpowojennym polityki równości, której centrum były kobiety.

Sukces powojennej polityki równościowej uzależniony był jednak od masowego członkostwa kobiet w SOLK, z czego działaczki partyjne zdawały sobie sprawę. Plan upowszechnienia Ligi jako organizacji masowej przedstawiała m.in. Irena Sztachelska, która w jednym z przemówień za cele stowarzyszenia uznawała: „planowe nie mechaniczne uporząkowanie organizacji poprzez ujęcie kół terenowych w zakładach pracy, $z$ oczywistym powiększeniem stanu posiadania", umasowienie rozumiane jako „zwerbowanie do Ligi Kobiet wszystkich kobiet zrzeszonych w ruchu zawodowym w Polsce oraz członkiń kół gospodyń Zw. Samopomocy Chłopskiej” oraz „dotarcie i włączenie do Ligi Kobiet niepracujacych zawodowo (gospodyń domowych miast) i zorganizowanie ich w koła terenowe, blokowe i domowe" ${ }^{\prime}$. W prasie działania organizacji przedstawiane były jako wszechstronne. Oceniając pierwszy rok działalności, w jednym z przedrukowanych przez „Kobietę” przemówień Sztachelska przedstawiała działalność Ligi jako obejmująca aktywizację polityczna kobiet, działania na rzecz aktywizacji zawodowej, działalność kulturalna oraz na arenie międzynarodowej. Przewodnicząca organizacji pisała:

\footnotetext{
„Jesteśmy wszędzie”, Kobieta, nr 10, 1948, 6-7.
}

9 „Liga Kobiet pracuje”, Kobieta, nr 7, 1948, 6. 
Liga Kobiet w 1947 r. przeprowadziła wiele pożytecznych i ważnych prac w skali społecznej i państwowej. Organizacja nasza wzięła czynny udział w wyborach do Sejmu Ustawodawczego. Na wiecach i zebraniach przedwyborczych dziesiątki tysięcy kobiet zrozumiały, jak wielka jest rola kobiety i jak ważny jest udział w życiu politycznym. Zrozumiały, że kobieta nie może pozostać na uboczu wobec przemian zachodzacych w ustroju politycznym i państwowym, że jej głos i decyzja jest $\mathrm{w}$ wielu sprawach nieodzowna. Kobieta - żona, matka i gospodyni nie może zamknąć się tylko w ścianach swojego domu. ... Nasze członkinie biora udział w wojewódzkich, powiatowych i miejskich Radach Narodowych, coraz bardziej wzrasta ich ilość. W sejmie mamy posłanki. Szereg kobiet objęło stanowiska wiceministrów, dyrektorów departamentów, naczelników wydziałów. Kobiety są dyrektorami fabryk, przedsiębiorstw, zakładów. ... Powierzono nam szkolenie zawodowe kobiet, w ramach trzyletniego planu gospodarczego. Organizujemy kursy, gdzie słuchaczki zdobywają fach. Tysiące kobiet szkoli się dziś i otrzymuje pracę. ... Liga Kobiet prowadzi dużą pracę oświatowa. $\mathrm{Na}$ zebraniach wygłasza się pogadanki, referaty, odczyty, zakłada się biblioteki, organizuje świetlice, przedstawienia amatorskie, chóry ... Zagadnienia społeczne, obywatelskie, gospodarcze i kulturalne, wychowanie dzieci, umiejętna organizacja pracy domowej, higiena, leczenie i zapobieganie chorobom to sa sprawy, które omawia się na naszych zebraniach. Członkinie interesują się życiem kobiet w innych krajach. Omawiają osiagnięcia i zdobycze zagranicznych organizacji kobiecych. Bierzemy udział w pracy na terenie międzynarodowym. Liga Kobiet jest członkiem Światowej Demokratycznej Federacji Kobiet. Zrzeszającej niemal wszystkie organizacje kobiece świata ... Widzimy, jak wiele wspólnych spraw nas łączy - wiemy, że wojna jest najstraszniejszym wrogiem każdej $z$ nas, bez względu na rasę, język, religię ${ }^{10}$.

Jak pisałam w innymi miejscu ${ }^{11}$, wśród powojennych działaczek kobiecych panowała zgoda co do tego, że umasowienie SOLK było priorytetem politycznym. Od liczebności organizacji działaczki kobiece PPR/ PZPR, a zarazem główne „projektantki” powojennej wizji równości kobiet w Polsce, uzależniały powodzenie swoich starań. Wśród członkiń aktywu kobiecego nie było natomiast zgody co do strategii pracy w ramach SOLK, w dyskusjach, jakie toczyły się podczas posiedzeń Wydziału Kobiecego,

10 Ibidem, 3.

11 Magdalena Grabowska, Zerwana genealogia, 203-211. 
widoczne było napięcie pomiędzy zwolenniczkami upolitycznienia projektu komunistycznej równości (do których zaliczała się Orłowska jako działaczka przede wszystkim komunistyczna) a proponentkami bardziej umiarkowanego podejścia do równości (do których zaliczała się np. Izolda Kowalska i wiele innych członkiń Ligi). Edwarda Orłowska swoją wizję SOLK prezentowała na łamach prasy kobiecej w serii artykułów opublikowanych w „Kobiecie” w 1948 r. Przedstawiała w nich spór między SOLK a PPR przede wszystkim jako konflikt klasowy pomiędzy robotnicami a inteligentkami, które jej zdaniem dominowały $\mathrm{w}$ organizacji kobiecej. „Powiedzmy sobie otwarcie - pisała Orłowska - czujemy się nieswojo w Lidze". I kontynuowała, cytując wypowiedź jednej z przedstawicielek łódzkiej SOLK: „Dosyć już dawać się prowadzić przez starościny, burmistrzowe, dyrektorowe! Te paniusie same nie pracuja, nie rozumieja przeważnie człowieka pracy, są puste wewnątrz. Niech one się najpierw ucza od nas"12. W swoich artykułach przewodniczaca Wydziału Kobiecego otwarcie wypowiadała się za upolitycznieniem Ligi, zaangażowaniem kobiet w bieżące wydarzenia polityczne w Polsce i na świecie oraz przeciwko temu, aby działania emancypacyjne koncentrowały się jedynie na tych aspektach życia kobiet, które wiąża je ze sferą prywatną. Pokpiwając $z$ dominującego jej zdaniem przekonania o tym, że „moda, dziecko, kośció1, kuchnia" stanowią krag zainteresowania kobiet, Orłowska przekonywała: „Kobiety musza wiedzieć, kto podżega do wojny, a kto broni pokoju. A to jest polityka. Kobiety muszą wiedzieć, dlaczego sa trudności $z$ mięsem i tłuszczem. A to jest polityka. Kobiety muszą wiedzieć, komu zależy na podburzaniu ciemnoty przeciw studentom. A to jest polityka"13.

\section{Zatrudnienie kobiet i dyskryminacja w miejscu pracy}

Aktywizacja społeczna, zawodowa i polityczna kobiet była w mniemaniu powojennych działaczek kobiecych warunkiem powodzenia politycznego projektu, jakim po wojnie była emancypacja kobiet. Jak pokazują badania historyczne, najwięcej miejsca poświęcono pracy zawodowej kobiet - ich „produktywizacja” była celem nadrzędnym, legitymizowanym zarówno przez potrzeby powojennego państwa polskiego, jak i założenia

12 Edwarda Orłowska, „Powiedzmy sobie otwarcie, czujemy się nieswojo w Lidze”, Kobieta, nr 47, 1948, 4.

13 Eadem, „Po co owijać w bawełnę”, Kobieta, nr 48, 1948, 7. 
ideologii komunistycznego projektu równości kobiet. Aktywizacja zawodowa, pełne zatrudnienie kobiet i awans społeczny były, jak pisze Natalia Jarska, sztandarowymi procesami, które miały świadczyć o modernizacji i postępowości nowego systemu ${ }^{14}$. Kwestie zwiazane $z$ bezrobociem kobiet, podejmowaniem przez nie pracy zawodowej oraz dotyczące opieki nad dziećmi, oświaty i edukacji, a także reformy systemu polityki społecznej, w tym prawa rodzinnego, stały się ważnymi tematami, którymi zajmowały się wydziały kobiece w pierwszych latach powojennych. Przypomnijmy, że także w Deklaracji Ideowej SOLK prawa kobiet rozumiane były przede wszystkim jako prawa matek i kobiet pracujacych ${ }^{15}$. W dokumencie tym czytamy m.in.:

Nasze Państwo demokratyczne zapewniło nam równouprawnienie. Dażyć będziemy do tego, by równouprawnienie to zostało wcielone w życie. Domagamy się za równą pracę równej płacy, abyśmy przy równych kwalifikacjach otrzymywały równe $z$ mężczyznami stanowiska, abyśmy miały dostęp do wszystkich szkół zawodowych, do wszystkich zawodów. Nie chcemy przywilejów, ale czuwać będziemy nad tym, by chroniąc kobiety, ustawodawstwo było przestrzegane. Osiagniemy to dzięki współpracy szerokich mas kobiecych w fabrykach i biurach, gospodyń domowych w miastach i na $\mathrm{wsi}^{16}$.

Piszac o aktywizacji kobiet do pracy zawodowej, również prasa kobieca nie pozostawiała watpliwości, że jest to priorytet polityki państwa. Wskazywano np., że choć szkolenia zawodowe prowadzi SOLK, „cała akcję finansuje Ministerstwo Pracy i Opieki Społecznej”. Edukacja kobiet zarówno na poziomie podstawowym (walka $z$ analfabetyzmem), jak i zawodowym (zapewnienie pełnego zatrudnienia oraz stworzenie możliwości łączenia pracy zawodowej z macierzyństwem) była kluczowa z punktu widzenia sprawnego i skutecznego włączenia kobiet do siły roboczej. W jednym z pierwszych numerów czasopisma „Kobieta” re-

\footnotetext{
14 Natalia Jarska, Kobiety z marmuru. Robotnice $w$ Polsce $w$ latach 1945-1960, (Warszawa : Instytut Pamięci Narodowej, 2015).

15 Dariusz Jarosz, „Idee, programy i realia: funkcje Ligi Kobiet w porzackku instytucjonalnym Polski Ludowej (1945-1957)”, w: Agnieszka Janiak-Jasińska, Katarzyna Sierakowska, Andrzej Szwarc (red.), Działaczki społeczne, feministki, obywatelki. Samoorganizowanie sie kobiet na ziemiach polskich po 1918 roku (na tle porównawczym), t. 2, (Warszawa : Neriton, 2008), 307-330.

16 Biblioteka Sejmowa, sygn. 000020236, Deklaracja ideowa Społeczno-Obywatelskiej Ligi Kobiet, 1947.
} 
daktorki w następujący sposób punktowały priorytety działań na rzecz „produktywizacji” kobiet. „Pierwszym etapem - pisały - jest szkolenie, które będzie odbywać się na razie na krótkoterminowych kursach". „Drugi etap - komunikowały - to zatrudnienie i zorganizowanie pracy”. Podkreślano jednocześnie, że w projektowaniu działań na rzecz wdrażania kobiet do pracy zawodowej kluczowe jest rozwiazanie kwestii opieki nad dziećmi, tak aby część kobiet mogła pracować poza miejscem zamieszkania, inne zaś miały możliwość pracy w domu. Redaktorki pisma argumentowały, że „przeszkolone kobiety moga pracować poza domem”. „Oczywiście te, którym warunki pozwalaja, zostaną zatrudnione w przedsiębiorstwach i fabrykach” zapewniały. Dodawały jednak: „Nierzadko ma to być system zarobkowania pomiędzy "kominem a kołyską", dlatego kluczową sprawą jest tworzenie spółdzielni wytwórczych”. Praca w spółdzielniach, jak pisano w „Kobiecie”, „ma być wykonywana w domu metodą chałupniczą"17.

Obecność kobiet na ważnych wysokich stanowiskach w polityce i nauce była wskaźnikiem postępu w dziedzinie równości w kraju. W jednym $z$ artykułów „Kobiety” zamieszczonych w cyklu „A co u nas?” przeczytać można było np.:

Czytelniczki nasze z przyjemnością dowiedzą się, że Ministerstwo Sprawiedliwości po raz pierwszy w dziejach naszego sądownictwa powierzyło funkcję sędziego sąu najwyższego kobiecie - p. Zofii Gawrońskiej, że z Krakowa wyjechała do Rzymu na zaproszenie Polskiej Ambasady i rzymskich placówek naukowych pierwsza w Polsce kobieta-doktor astronomii, dr Stankiewicz, która wygłosi w Rzymie cykl wykładów z zakresu matematyki stosowanej, że niezwykle interesujacych odkryć archeologicznych na pograniczu małopolsko-wielkopolskim młoda uczona polska - mgr Alina Kotlińska, przeprowadzając badania $\mathrm{w}$ przechowywanym do dni dzisiejszych grodzisku słowiańskim na Górze Zamkowej w Cieszynie, gdzie odkryła wykopaliska z VI wieku ${ }^{18}$.

Przekonanie, że kobiety sa w stanie sprawdzić się na wszystkich poziomach „pracy produkcyjnej”, w tym jako osoby sprawujace funkcje kierownicze, i że jednym $z$ celów równouprawnienia jest uobecnienie kobiet na tych stanowiskach, było od początku widoczne w tekstach

17 „A co u nas?”, Kobieta, nr 9, 1948, 3.

18 Ibidem, 2. 
publikowanych w czasopismach kobiecych, w tym także w „Kobiecie”. W artykule Tam gdzie dyrektorem jest kobieta, który ukazał się w lutym 1948 r., Edwarda Orłowska opisywała pracę Zofii Szydłowskiej, dyrektorki Państwowych Zakładów Przemysłu Wełnianego w Łodzi. Osią artykułu była, co ciekawe, kwestia dyskryminacji kobiet w miejscu pracy, a polityczka zadała pytanie, jakie działania należałoby podjąc na rzecz poprawy kondycji pracujących kobiet. Orłowska cytowała swoja bohaterkę, która mówiła: „Nie ma Pani pojęcia, jaką walkę musiałam stoczyć i staczam codziennie ... ile dodatkowej energii zużywam, by udowodnić, że chociaż jestem kobieta, potrafię pracować nie gorzej niż mężczyzna". Autorka dodawała: „Pani dyrektor dzieli się ze mna swymi kłopotami i troskami. Przykro jej, że w Radzie Zakładowej na 15 członków - nie ma ani jednej kobiety. Rada ta była wybrana już dawno - zanim ona zaczęła tu pracować”. Swój artykuł Orłowska kończyła optymistycznie, przekonując, że wdrażane przez państwo instrumenty na rzecz wyrównania pozycji zawodowej kobiet przyczynią się do poprawy sytuacji osób takich jak Szydłowska. Autorka podkreślała, że nowa dyrektorka wiele już zrobiła dla pracujących w fabryce kobiet, przede wszystkim zapewniając im opiekę dla dzieci oraz możliwość odpoczynku. „Przy fabryce jest ambulatorium” opisywała. „W dawnym pałacu fabrykanta - mieści się przedszkole. Jest również żłobek. Ładnie rozwija się praca świetlicowa” ${ }^{19}$.

Prasa kobieca wiele miejsca poświęcała też zasadzie równej płacy za taką sama pracę. „Kobiecie pracującej przysługują te same prawa, które przysługuja mężczyźnie” przekonywała na łamach „Kobiety” Maria Staniszkis, wskazując jednocześnie, że równość ta dotyczy przede wszystkim kwestii płac:

Naczelną zasada wprowadzoną i stosowaną w Polsce Ludowej jest zrównanie płac kobiet i mężczyzn za tę samą pracę. Pracodawca nie może gorzej opłacać tej samej pracy kobiety i mężczyzny, nie może płacić mniej kobiecie, nawet za jej zgoda. Ta kardynalna zasada ustroju demokratycznego zawarta w przepisach Manifestu Polskiego Komitetu Wyzwolenia Narodowego i Konstytucji nie może być omijana przez sztuczne stwarzanie różnic w wykonywanej pracy, celem uzasadnienia różnej płacy ${ }^{20}$.

19 Edwarda Orłowska, „Tam gdzie kobieta jest dyrektorem”, Kobieta, nr 10, 1948, 7.

20 Maria Staniszkis, „Ochrona pracy kobiet”, Kobieta, nr 18, 1948, 3. 
Organizowanie pracy zawodowej kobiet wiązało się $z$ umożliwieniem im łączenia obowiązków zawodowych $z$ domowymi, przede wszyst$\operatorname{kim} z$ wychowywaniem dzieci i prowadzeniem gospodarstwa domowego. Dyskurs macierzyński był obecny w polskim powojennym projekcie emancypacyjnym już od lat tużpowojennych. Nowe świeckie święta, jak Dzień Kobiet i Dzień Matki, stały się okazją do uhonorowania wielodzietnych matek, a dla SOLK opieka nad matką i dzieckiem była jednym z najważniejszych obszarów działania. Jak wskazują badaczki organizacji: Małgorzata Fidelis, Anna Nowakowska-Wierzchoś czy Barbara Nowak, dla organizacji kobiecych i partii komunistycznej zapewnienie dobrostanu rodziny było ważne również z powodów politycznych - niezadowolone kobiety mogły się przyczynić do buntów społecznych i strajków ${ }^{21}$.

\section{Praca domowa - uspołecznienie i równy podzial obowiązków domowych}

Aby umożliwić kobietom łączenie nowych ról zawodowych $\mathrm{z}$ macierzyństwem, zmieniające się po wojnie prawo dotyczące kobiet koncentrowało się nie tylko na kwestii pracy zawodowej, lecz także, a może przede wszystkim na prawie cywilnym. Wprowadzenie w 1945 r. cywilnych rozwodów oraz uznanie legalności dzieci spoza małżeństwa stało się poczatkiem wielkich zmian obyczajowych w Polsce. Redaktorki „Kobiety” starały się wyjaśnić i przybliżyć kobietom te zmiany, jednocześnie umniejszając ich potencjalny wpływ na tradycyjna rodzinę oraz relacje między płciami. Wskazywały również, że prawa te chronią kobiety, uniemożliwiając mężczyznom „łatwe” uzyskanie rozwodu bez orzeczenia o winie. W artykule poświęconym nowemu prawu rozwodowemu Grażyna Glińska pisała:

Nie wiadomo dlaczego wśród wielu kobiet panuje przekonanie, że od czasu obowiązywania nowego prawa małżeńskiego rozwód można otrzymać bardzo łatwo, że mężowie moga porzucać żony i uzyskaw-

\footnotetext{
${ }^{21}$ Małgorzata Fidelis, Kobiety, komunizm i industrializacja $w$ powojennej Polsce (Warszawa : WAB, 2015); Anna Nowakowska-Wierzchoś, „Społeczno-Obywatelska Liga Kobiet 1945-1949 i Zwiazek Kobiet Polskich im. Marii Konopnickiej we Francji (1944-1950) dokumenty programowe", Komunizm: System-Ludzie -Dokumentacja. Rocznik Naukowy, t. 2, 2013, 251-279; Barbara Nowak, Serving women and the State. The League of Women in Communist Poland, (PhD thesis : Uniwersytet Ohio, 2004). [Dostęp: 29.11.2019]. Dostępny w World Wide Web: <https://bit.ly/2LWC6nT>.
} 
szy bez żadnych trudności rozwód, poślubić inne kobiety. Przekonanie takie jest niczym niepoparte. Prawo małżeńskie obwiazujące od 1 stycznia $1946 \mathrm{r}$. oraz dotychczasowa praktyka sadowa twardo stoja na gruncie ochrony interesów rodziny, biorąc w obronę dzieci i tego małżonka, który jest niewinny rozkładu pożycia małżeńskiego ... Rozwodu może żądać jeden $z$ małżonków $z$ powodu stałego rozkładu pożycia małżeńskiego ... Orzeczenie Sądu Najwyższego z dnia 13 listopada 1946 podkreśla jeszcze mocniej, że rozwodu może żądać tylko małżonek niewinny, a nie ten, który doprowadził do rozkładu małżeńskiego pożycia ${ }^{22}$.

Jednocześnie na łamach pisma ukazywały się porady prawne dotyczace przede wszystkim kwestii rozwodowych, rozwiąywania sytuacji rodzinnych, alimentów. Podejmowano również kwestie zwiąane $z$ zatrudnieniem, w tym m.in. w spółdzielniach, wypowiedzeniem umowy o pracę zawartej $z$ pracownikiem umysłowym na czas nieokreślony oraz odszkodowaniami.

Równość kobiet, która była stopniowo wprowadzana po $1945 \mathrm{r}$. jako część nowego systemu, nie wiązała się z polityczna debatą na temat upublicznienia prac domowych - choć dyskusja taka toczyła się w ramach tzw. aktywu kobiecego i na łamach prasy kobiecej. W „Kobiecie" sprawa równości kobiet w miejscu pracy była od samego początku ukazywana jako nierozerwalnie spleciona $z$ pytaniem o pracę domowa. Redakcja pisma widziała sfere pracy zawodowej i pracy domowej jako zależne od siebie, a w przypadku kobiet wskazywała na konieczność wykonywania nieodpłatnej pracy domowej jako dodatkowe obciązenie dla kobiet pracujących zawodowo lub uczacych się, a także jako niesprawiedliwość z punktu widzenia równości płci. Na przełomie lat 1947/1948 „Kobieta” stała się forum wymiany opinii odnośnie do pracy domowej dziewcząt i kobiet. Jednym $z$ pierwszych tekstów na temat podwójnego obciażenia był opublikowany wiosna 1948 r. artykuł zatytułowany Praca domowa dziewczat autorstwa Wandy Łempickiej ${ }^{23}$. W duchu promowanych w tamtym czasie zaleceń dotyczacych edukacji kobiet i prowadzenia domu autorka forsowała opinię, zgodnie $z$ którą ważnym elementem życia kobiet w nowych okolicznościach politycznych i społecznych po 1945 r. była konieczność wypracowania równowagi pomiędzy emancypa-

22 Elżbieta Glińska, „O rozwodach”, Kobieta, nr 10, 1948, 17.

${ }^{23}$ Wanda Łempicka, „Praca domowa dziewczat””, Kobieta, nr 3, 1947, 6. 
cją, wyrażaną m.in. w dążeniu do podwyższenia poziomu wykształcenia wśród młodych kobiet, a tradycyjnymi rolami płciowymi, wciąż mocno zakorzenionymi w Polsce (i nie tylko). Konieczność angażowania kobiet w obowiazki domowe autorka przedstawiała jako kwestie praktyczna problem społeczny do rozwiazania. Argumentowała zatem:

Dwa cele można by mieć na względzie [rozważając kwestię pracy domowej dziewczat $]$. Przede wszystkim cel praktyczny - przygotowanie dziewczat do samodzielnego dawania sobie rady $z$ gospodarstwem ... W wielkich miastach racjonalizacja pracy domowej, różne wynalazki i udogodnienia starają się przyjść kobiecie z pomoca, ale skuteczniejszą pomoca stanie się dla kobiety jeśli się będzie na gospodarstwie znała i jeżeli od młodości nabędzie wprawy w łączeniu zajęć domowych $z$ innymi ${ }^{24}$.

Za drugi ważny cel angażowania dziewcząt w pracę domową Łempicka uznawała „kształcenie obowiązkowości i odpowiedzialności każdego członka rodziny za sprawny bieg życia domowego". Zdaniem Łempickiej to matki miały wdrażać młode kobiety do pracy w domu. Wskazując na sposób, w jaki mogłyby je zachęcać do zaangażowania w obowiązki zwiazane $z$ dobrym funkcjonowaniem rodziny, autorka pisała: „Nie podnosimy drobnych niedociagnięć i usterek, nie żałujemy pochwał w rodzaju "Jak dobrze, że pomyślałaś o przygotowaniu posiłku - inaczej ojciec byłby poszedł głodny"”25.

Tak sformułowany punkt widzenia Łempickiej spotkał się z krytyką Wandy Melcer, regularnie publikującej w „Kobiecie” rubrykę zatytułowaną Rozległa galeria matek oraz odpowiedzialnej w piśmie za recenzje teatralne i filmowe. O ile podzielała ona opinię Łempickiej o konieczności edukowania młodzieży na temat sprawnego funkcjonowania życia rodzinnego i obowiazków domowych, o tyle przypominała, że płeć nie powinna być czynnikiem różnicującym taką edukację. Pisała:

Możemy więc zgodzić się $z$ autorką wtedy jedynie, kiedy będziemy rozpatrywać pracę domowa młodzieży w domu bez względu na płeć, zakładamy bowiem, że w domu pracuja wszyscy, a co za tym idzie wszyscy maja jednakie prawa, jednakie obowiąki. Nic między praca-

\footnotetext{
24 Ibidem.
}

25 Ibidem. 
mi domowymi nie ma takiego, co nie byłoby po równo przeznaczone mężczyźnie czy kobiecie, chłopcu czy dziewczynie ${ }^{26}$.

W podobnym duchu wypowiadały się czytelniczki pisma. Jedna $z$ nich, Janina Koźmińska $z$ Wrocławia, w przesłanym do działu Listy Stefanii manifeście dotyczacym pracy domowej, utrzymywała, że równy podział obowiąków w rodzinie jest kwestia sprawiedliwości społecznej, a utrwalone wśród wielu mężczyzn i kobiet przekonanie na temat „kobiecości” prac domowych stanowi pozostałość „złego wychowania” mężczyzn, które miało charakter aspołeczny i było przykładem błędnie pojmowanej istoty męskości. W liście do redakcji zatytułowanym To nie męska rzecz czytelniczka pisała:

Jest rzeczą wysoce niespołeczna, by maż przyszedłszy z pracy do domu, wypoczywał $\mathrm{w}$ fotelu $\mathrm{z}$ gazeta lub czekał bezczynnie na posiłek, podczas gdy żona często organicznie słabsza, po przyjściu z pracy krząta się w kuchni, podaje posiłek, zmywa naczynia, by wreszcie dla rozrywki wysprzatać mieszkanie i wycerować męża bieliznę. A wykonuje te wszystkie czynności sama, bez udziału męża, bo to nie jest męska rzecz. Kochane towarzyszki niedoli! Nazwijmy rzecz po imieniu: męskość, której szkodzi bliższy kontakt z igła lub miotła, jest chyba wattpliwego gatunku. To jest po prostu egoizm i złe wychowanie. To można i należy zmienić. Wychowajmy typ nowoczesnego mężczyzny ${ }^{27}$.

Na poziomie instytucjonalnym za kwestię łączenia pracy domowej z zawodowa miał odpowiadać m.in. powołany w 1947 r. Instytut Gospodarstwa Domowego. Opisując założenia kierowanej przez siebie jednostki, Irena Gumowska odniosła się do szeroko dyskutowanej na łamach „Kobiety” kwestii pracy domowej. Podobnie jak jej redakcyjne koleżanki, także Gumowska była zdania, że ostatecznie sprawa ta powinna być rozwiazana przez państwo poprzez przeniesienie pracy wykonywanej w ramach indywidualnych gospodarstw na barki „gospodarstwa zbiorowego". Dyrektorka IGD pisała:

Kobiety dziś muszą i w większości chca pracować. Jest to poza tym w interesie państwa, którego ludność zmniejszyła się o 1/2. Pracujacc 7 do 8 godzin, tak jak mężczyzna, kobieta nie ma możności ani sił

\footnotetext{
26 Wanda Melcer, „Warszawa-Sidney”, Kobieta, nr 10, 1948, 7.

27 „Listy do Stefanii”, Kobieta, nr 19, 1948, 12.
} 
na dobre prowadzenie swego domu. ... Nie mogac unowocześnić gospodarstwa indywidualnego, stworzyliśmy to, co można było w Polsce zaraz po wojnie najracjonalniejszego: stworzyliśmy różne formy gospodarstw zbiorowych. Tutaj na pierwszym miejscu stoją stołówki, żłobki i przedszkola. Dalej Domy Matki i Dziecka, dalej spółdzielcze pralnie, spółdzielcze piekarnie wiejskie, organizuje się spółdzielnie usługowe. Nie mamy jeszcze perspektyw lat, aby docenić i widzieć rewolucyjna rolę, jaką w naszym życiu odgrywa to, co ujęliśmy nazwa gospodarstwa zbiorowego w szerokim znaczeniu. Szczególnie wyraźnie zarysowuje się to w miastach. np. jeżeliby stołówki stanęły na takim poziomie, jakiego należy się po nich spodziewać, byłyby jednym $z$ największych dobrodziejstw naszych czasów. Wyrugowanie codziennego przyrządzania obiadów w domu pociaga za sobą bardzo poważne skutki. Zmienia kuchnie - co musi mieć wpływ na budownictwo, inne sa potrzeby urządzenia wnętrza, inaczej rozkłada się dzień pracy domowników. Dzięki żłobkom, przedszkolom, wiele matek może pracować zawodowo. Spółdzielcze pralnie, pralnie Ligi Kobiet w większych zbiorowiskach pracy staraja się usunąć kłopot prania domowego. To samo dotyczy szwalni i spółdzielczych zakładów krawieckich. Przemysł konfekcyjny produkujacy standardowe ubrania i odzież po niskiej cenie wytraci $z$ czasem w dużej mierze $z$ rak gospodyni uprzykrzoną igłę ${ }^{28}$.

Rozważania na temat kobiecości i męskości, płci i feminizmu rzadko w „Kobiecie” wychodziły poza poziom praktyczny. Na kwestie zwiąane $z$ prawami, równościa i sprawiedliwością społeczna patrzono przede wszystkim ze względów praktycznych - równość kobiet i mężczyzn miała się przyczynić do lepszego funkcjonowania społeczeństwa, rodziny i poszczególnych osób, była ukazywana jako warunek dobrostanu na tych trzech poziomach życia społecznego. Była też jednak widziana jako sprawa polityczna, gdyż obok równości klasowej i rasowej stanowiła dowód wyższości komunizmu nad kapitalizmem, w którym, jak argumentowano, kobiety nie cieszyły się podobnym zakresem praw jak w krajach socjalistycznych. Równość płci traktowano także czasem jako problem obyczajowy, zwyczajów lub przyzwyczajeń, a nierówność jako obecne w społeczeństwie przesądy i zabobony.

Niezwykle rzadko pojawiały się natomiast teksty dotyczace filozoficznych rozważań na temat równości. Znaczacym wyjątkiem był więc

${ }_{28}$ Irena Gumowska, „Gospodarstwo domowe”, Kobieta, nr 41, 1948, 21. 
opublikowany w 1948 r. artykuł Ireny Krzywickiej pod wymownym tytułem Nowy matriarchat. Autorka analizowała w nim kwestie równouprawnienia $z$ perspektywy czasowej, a także ogólnych relacji między płciami. Rozważając równość kobiet i mężczyzn, odżegnywała się od feminizmu, co było zgodne $z$ obowiazujacym w owym czasie przekazem ${ }^{29}$. Piszac, $\dot{z} \mathrm{e}$ jej światopogląd nie jest wynikiem „ideologii”, lecz obiektywnej obserwacji faktów, Krzywicka dowodziła:

Nie mówię tak dlatego, żebym była feministka (feminizm wydaje mi się komiczny). Ale dlatego, że taka jest obiektywna prawda. Dawna kobieta była ekonomicznie słabsza od mężczyzny i stąd pochodziła jej od niego zależność. Dziś ta sytuacja się skończyła, natomiast prawa natury zostały niezmienne. Dziś sytuacja kobiety przypomina raczej stosunki panujące $\mathrm{w}$ przyrodzie $\mathrm{u}$ większości przedstawicieli świata zwierzęcego, gdzie samiec jest potrzebny tylko na krótką chwilę zapłodnienia, a poza tym samica daje sobie radę zarówno ze soba, jak i z utrzymaniem ciagłości gatunku ${ }^{30}$.

\section{Polski i międzynarodowy ruch kobiecy - Światowa Demokratyczna Federacja Kobiet}

Wiele badaczek podejmujących tematykę równości kobiet po 1945 r. wskazuje, że programy równości w Europie Wschodniej i na Zachodzie nie były formułowane w międzynarodowej próżni, bez kontaktu z kobiecymi organizacjami ${ }^{31}$. ŚDFK, która powstała w 1945 r. w Paryżu, odegrała bardzo ważna rolę w kształtowaniu strategii międzynarodowego ruchu kobiecego w pierwszych latach powojennych. Założycielki organizacji, m.in. Eugénie Cotton i Marie-Claude Vaillant-Couturier, definiowały jej cele jako skupiające się na czterech obszarach: antyfaszyzmie, międzynarodowym pokoju, dobrostanie dzieci i statusie kobiet. Równość ekonomiczna kobiet, w tym równość płac, była jednym z kluczowych postulatów Federacji od początku jej istnienia. W 1948 r. w przedsta-

\footnotetext{
29 Irena Krzywicka „Nowy matriarchat”, Kobieta, nr 7, 1948, 18.

30 Ibidem.

${ }^{31}$ Francisca de Haan, „The Global Left-Feminist 1960s. From Copenhagen to Moscow and New York", w: Chen Jian, Martin Klimke, Masha Kirasirova, Mary Nolan, Marilyn Young, Joanna Waley-Cohen (red.), The Routledge Handbook of the Global Sixties. Between Protest and Nation-building, (London : Routledge, 2018), 230-242.
} 
wionym podczas obrad Kongresu Kobiet w Budapeszcie raporcie ŚDFK deklarowano: „Wielka niesprawiedliwość wbudowana w nierówną płacę za ta sama pracę jest wzmagana przez dyskryminację kobiet, która jest często wynikiem braku zabezpieczeń społecznych dla matek"32. W dokumencie uznawano nierówność ekonomiczna kobiet, „nierówność wynagrodzeń" za najbardziej dojmująca niesprawiedliwość społeczną. Autorki dodawały jednocześnie, że w „większości krajów kapitalistycznych kobiety nie mogą cieszyć się z praw ekonomicznych równych mężczyznom"33.

Działalność ŚDFK w latach 1945-1969 opierała się przede wszystkim na trzech filarach: organizacji (światowych) Kongresów Kobiet, przygotowywaniu porównawczych raportów na temat równości w rozmaitych dziedzinach życia (w tym w polityce, sferach ekonomicznej i świadczeń społecznych) oraz na współpracy z różnymi innymi organizacjami międzynarodowymi, takimi jak Światowa Federacja Zwiąków Zawodowych, Międzynarodowa Organizacja Pracy czy Światowa Organizacja Zdrowia. W okresie 1945-1969 Federacja zorganizowała sześć Kongresów Kobiet, czyli międzynarodowych spotkań organizacji kobiecych. Pierwszy z nich odbył się w Paryżu w 1945 r., drugi w Budapeszcie w 1948 r., trzeci w Kopenhadze w 1953 r., czwarty w Wiedniu w 1958 r., piąty w Moskwie w 1963 r., a ostatni szósty Kongres w Helsinkach w 1969 r. Podczas tych spotkań przedstawiano raporty na temat sytuacji kobiet w różnych dziedzinach życia. Organizacja monitorowała postęp i osiagnięcia w zakresie równości płci, opierając się, podobnie jak później Organizacja Narodów Zjednoczonych, na danych dostarczanych przez rządy poszczególnych krajów i delegatki organizacji należących do Federacji. W 1948 r. ŚDFK liczyła 51 organizacji członkowskich reprezentujacych takie kraje, jak m.in. Włochy, Francja, Hiszpania, Wielka Brytania, Belgia, Grecja, Chiny, Korea, Szwecja, Niemcy, Indie, Rumunia, Czechosłowacja, Węgry, Wietnam, Argentyna, Dania czy Finlandia. Od 1947 r. ŚDFK była organizacją doradczą Rady Społeczno-Ekonomicznej Organizacji Narodów Zjednoczonych, w tym Komisji ds. Statusu Kobiet. Jej przedstawicielki mogły uczestniczyć w spotkaniach obu ciał i miały dostęp do dokumentów oraz materiałów powstających w ramach ONZ.

32 WIDF (Women's International Democratic Federation), Second Women's International Congress. Account of the Work of the Congress Which Took Place in Budapest (Hungary) from the 1st to the 6th of December 1948, (Paris : Women International Democratic Federation, 1948), 286.

33 Ibidem, 283. 
W ramach wyznaczonych przez powojenna politykę międzynarodową delegatki $z$ krajów socjalistycznych najpełniej reprezentowały ducha polityki ŚDFK. Ponieważ nasz kraj przechodził właśnie transformację od kapitalizmu do socjalizmu i miał za sobą najbardziej dojmujące doświadczenia II wojny światowej, Polki świadczyły o sukcesach socjalistycznej równości płci i głosiły konieczność walki o światowy pokój. W swoich wystapieniach na forum międzynarodowym kładły nacisk na skok cywilizacyjny, jaki w ich opinii dokonał się w socjalistycznej Polsce w kwestii praw kobiet. Porównując sytuację przed wojna (w kapitalistycznej Polsce) i po wojnie (w Polsce socjalistycznej), Eugenia Pragierowa mówiła:

Przed wojna nauczycielka lub kobieta zatrudniona na stanowisku administracyjnym traciła swoją posadę $z$ chwila wyjścia za mą̇, kobieta z dziećmi znajdowała wszystkie drzwi zamknięte, zaś kobieta w ciąży, która musiała sama zarobić na swoje utrzymanie, była w sytuacji bez wyjścia. W chwili obecnej mój kraj robi wszystko, co jest konieczne, aby kobieta była $\mathrm{w}$ stanie pogodzić pracę zawodowa $\mathrm{z}$ głównym obowiązkiem, jakim jest bycie matką i edukacja dzieci. Kobiety pracujące otrzymuja w Polsce 12 tygodni płatnego urlopu w okresie urodzenia dziecka. W szóstym miesiącu ciaży kobieta jest przesuwana do lżejszej pracy bez uszczerbku na zarobkach. Kobieta może korzystać ze szczególnych usług i praw pierwszeństwa w zakończeniu lub przerwaniu swoich obowiazków zawodowych. Całkowita pomoc w związku $z$ ciąża i zapomoga jest dana kobietom za darmo, włącznie $z$ wyprawką dla dziecka ${ }^{34}$.

W narracjach dotyczacych praw politycznych polskie delegatki wskazywały również na nierozłączność różnych obszarów równości, m.in. nierozdzielność praw w sensie ekonomicznym i politycznym. W $1953 \mathrm{r}$. Pragierowa mówiła na forum ŚDFK:

Możliwość realizacji wszystkich praw politycznych jest wdrażana w Polsce przez fundamentalny warunek pełnej ekonomicznej równości - równości, która daje kobietom pewność równego prawa do pracy, płacy, studiowania i awansu. ... Rozwój naszej gospodarki sprawia, że każda kobieta mająca możliwość i chcaca pracować znajdzie zatrudnienie odpowiednie dla niej, zgodne $z$ jej gustem i umiejętnościami.

34 Ibidem, 230. 
Zasada równej płacy za taką samą płacę jest stosowana rygorystycznie i stała się żelazną zasada życia codziennego w naszym kraju. Specjalna dyspozycja została wydana i każda inicjatywa, i każda instytucja stała się odpowiedzialna za dostarczenie odpowiedniego miejsca pracy dla każdej kobiety - szczególnie zaś dla tych, które sa nowo zatrudnione - by wciaż mogły uczestniczyć w profesjonalnym treningu tak, aby w przyszłości mieć szansę szybkiego awansu na wyższe stanowiska ${ }^{35}$.

W kontekście rozpoczynającej się właśnie zimnej wojny ŚDFK stanowiła forum spotkania między zachodnimi socjalistkami i komunistkami działajacymi w ruchach antyfaszystowskich, „progresywnych” i antyrasistowskich a reprezentantkami bloku wschodniego. W publikowanej w Polsce prasie kobiecej wiele pisano o działalności ŚDFK, jej celach, założeniach i członkiniach. Redakcja „Kobiety” niebywale duża wagę przywiazywała do prezentowania postępów ruchu kobiecego na arenie międzynarodowej. Relacje $z$ obrad ŚDFK były zamieszczane na pierwszych stronach pisma. W artykułach tych niezwykle szczegółowo omawiano działania Federacji, opisując jej cele, poszczególne liderki międzynarodowego ruchu kobiecego, a także powiązania między wdrażaniem równości kobiet na poziomie międzynarodowym i krajowym. Jesienią 1948 r. gazeta opisywała np. wizytę Eugénie Cotton oraz delegatek organizacji kobiecych ze Stanów Zjednoczonych, Anglii, Francji i Brazylii na Kongresie Intelektualistów we Wrocławiu. Relacjonowano spotkanie przedstawicielek ŚDFK z działaczkami SOLK, podkreślając wspólne cele organizacji - walkę o pokój i równouprawnienie kobiet. Wśród opisywanych przez „Kobietę” gości była m.in. Bella Abzug, amerykańska prawniczka, późniejsza działaczka na rzecz praw kobiet, która m.in. z Betty Friedan, Shirley Chisholm, Pauli Murray czy Muriel Fox założyła Narodową Organizację Kobiet (National Organization for Women, NOW), a później była przewodnicząca Narodowej Komisji ds. Przestrzegania Postanowień Międzynarodowego Roku Kobiet. Jak donoszono w „Kobiecie”, podczas swojej wizyty w Polsce w 1948 r. „pani Abzug zainteresowała się specjalnie działalnością Ligi Kobiet w zakresie szkolenia zawodowego i zatrudnienia kobiet, zwiedzała między innymi spółdzielnie pracy”. Podsumowując, sprawozdawczyni gazety uznała, iż „bez zbytniej skromności możemy stwierdzić na podstawie wypowiedzi naszych gości,

35 WIDF, World Congress of Women. Reports, Speeches (Extracts). Documents, (Berlin : Women's International Democratic Federation, 1953), 229. 
że osiagnięcia polskich kobiet sa nie tylko doceniane, ale i podziwiane przez działaczki kobiece $z$ innych krajów, są też zachętą do pracy dla tych kobiet $z$ tych krajów, gdzie organizacje kobiece sa jeszcze słabe i walcza $z$ dużymi trudnościami" ${ }^{36}$.

Prasa kobieca w Polsce relacjonowała, w jaki sposób działalność na rzecz równości kobiet na poziomie międzynarodowym przenika się $z$ aktywnościami podejmowanymi w kraju. W ramach cyklu Liga Kobiet Pracuje pisano: „Przy Zarządzie Głównym Ligi Kobiet została zorganizowana Polska Sekcja Komisji Informacji i Propagandy ŚDFK. Komisja informuje społeczeństwo polskie o celach, zadaniach i osiagnięciach ŚDFK o rozwoju ruchu kobiecego na świecie. Obecnie komisja przygotowuje materiały do Międzynarodowej Wystawy Kobiecej w Paryżu, która ma być zorganizowana przez ŚDFK w czerwcu br.”. Informacje na temat ŚDFK pojawiały się najczęściej w kontekście obchodów dni świątecznych związanych $z$ kobietami, a więc Dnia Kobiet i Dnia Matki. W marcu 1948 r. w tekście zatytułowanym 8 Marca - Międzynarodowy Dzień kobiet redaktorki opisywały powstanie ŚDFK jako dowód na pojawienie się nowej fali międzynarodowego ruchu na rzecz równości kobiet ${ }^{37}$. W artykule tym ujawniło się przekonanie o powojennym postępie w dziedzinie praw kobiet - nie był on dla autorek ani okresem reakcji, ani zastoju. W obliczu postępującej dekolonizacji i wprowadzania prawnych gwarancji na rzecz równości w bloku wschodnim autorki uznały okres powojenny za szczególnie aktywny jeśli chodzi o emancypację. Jednocześnie ponadnarodowy i ponadrasowy charakter działań ŚDFK miał być świadectwem przekraczania ograniczeń stawianych zarówno przez ograniczające postęp kultury lokalne, jak i międzynarodowe siły przyczyniające się do opresji kobiet (i opresji rasowej), takie jak kapitalizm, kolonializm, militaryzm czy imperializm. W artykule $z$ okazji 8 marca czytamy więc:

Po wojnie ruch kobiecy ożył i wzmógł się na sile. Skoordynowały się, złączyły wysiłki kobiet poszczególnych krajów z chwilą powstania wielkiej organizacji Światowej Demokratycznej Federacji Kobiet. ... Coraz więcej narodów zgłasza swój udział do Federacji. Hasła jej docierają do kobiet w krajach kolonialnych. Kobiety białe, czarne i żółte, bo kolor skóry nie gra żadnej roli, biora udział w naradach, jak ulepszyć życie świata, jak obalić przesady, które utrudniają życie kobiety, jak zapew-

36 „A co u nas”, Kobieta, nr 48, 1948, 7.

37 „8 Marca - Międzynarodowy Dzień Kobiet”, Kobieta, nr 10, 1948, 2. 
nić stały sprawiedliwy pokój. ... Liga Kobiet jest członkiem Federacji od chwili jej powstania. ... Czujnymi oczyma patrzymy na to, co dzieje się dziś na świecie. I widzimy tragiczne zmagania o wolność i demokracje w Hiszpanii, w Grecji, w Chinach, Indonezji, Vietnamie. Widzimy, jak tysiace ludzi umiera, jak rozstrzeliwane są walczace kobiety, jak męcza się dzieci i ludność tych krajów. Widzimy zaborcze plany kapitalizmu amerykańskiego ${ }^{38}$.

\section{Ze wschodu na zachód?}

Współczesne badania historyczne pokazuja, że wizje emancypacyjne wdrażane w Europie Wschodniej były promowane na forum ONZ i ŚDFK. Działania na rzecz emancypacji kobiet w regionie pokrywały się również z celami progresywnych ruchów kobiecych na Zachodzie, w tym w Stanach Zjednoczonych, których działania stały się podwalina formujących się w kolejnych dekadach ruchów kobiecych (także tzw. drugiej fali feminizmu) ${ }^{39}$. Organizacją członkowska Ś SFK był Kongres Kobiet Amerykańskich (Congress of American Women, CAW), który powstał w Nowym Jorku w marcu 1946 r. i zrzeszał „progresywne” kobiety amerykańskiej lewicy ${ }^{40}$. Była wśród nich m.in. Gerda Lerner, absolwentka New School for Social Research, pionierka historii kobiet jako dyscypliny naukowej, działaczka antyfaszystowska, a w latach późniejszych współzałożycielka Narodowej Organizacji Kobiet (National Organization for Women, NOW), sztandarowej organizacji drugiej fali amerykańskiego feminizmu (organizacja powstała w 1966 r.), oraz obserwatorka w Komisji do Spraw Kobiet ONZ ${ }^{41}$. Inną członkinią Kongresu była antropolożka Gene Weltfish, wykładowczyni Columbia University i współautorka, wraz $z$ Ruth Benedict, broszury pt. The Races of Mankind, w której argumen-

\footnotetext{
38 Ibidem.

39 Jacqueline Castledine, Cold War Progressives. Women's Interracial Organizing for Peace and Freedom, (Urbana-Chicago : University of Illinois Press, 2012); Daniel Horowitz, Betty Friedan and the Making of "The Feminine Mystique". The American Left, the Cold War, and Modern Feminism, (Amherst : University of Massachusetts Press, 1998); Erik S. McDuffie, Sojourning for Freedom. Black Women, American Communism, and the Making of Black Left Feminism, (Durham, N.C. : Duke University Press, 2011).

40 Kate Weigand, Red Feminism. American Communism and the Making of Women's Liberation, (Baltimore-London : Johns Hopkins University Press, 2001).

${ }^{41}$ Gerda Lerner, Fireweed. A Political Autobiography, (Philadelphia : Temple University Press, 2002).
} 
towały, że postrzegane różnice między rasami mają charakter kulturowy, a nie biologiczny ${ }^{42}$. Amerykańskie delegatki do ŚDFK podzielały dominujące w Federacji przekonanie, iż równość jest możliwa jedynie w komunizmie, i właśnie ono stało się przyczyną prześladowań politycznych, których doświadczały ze strony rodzimych polityków i amerykańskiej opinii publicznej.

W uznawanym za kluczowy dokumencie programowym Kongresu zatytułowanym „Raport na temat statusu kobiet” autorstwa Susan B. Anthony (Drugiej) czytamy przede wszystkim, że cele i strategie organizacji sa zbieżne $z$ misja Ś SFK. Praca zarobkowa kobiet w tym czasie była, podobnie jak w Europie Wschodniej, głównym postulatem organizacji progresywnych w USA, w tym Kongresu Kobiet Amerykańskich, który domagał się zapewnienia kobietom dostępu do satysfakcjonujących miejsc zatrudnienia w obliczu zmniejszającej się po wojnie liczby miejsc pracy. Jak podkreślała autorka dokumentu, kobiety w okresie powojennym stały się ofiarami masowych zwolnień z pracy, spowodowanych przede wszystkim powrotem mężczyzn $z$ wojny. Traciły miejsca pracy głównie w przemyśle, były eliminowane $z$,męskich” zawodów, w szczególności w przemyśle ciężkim, stoczniach i lotnictwie. Jednocześnie w drugiej połowie lat 40. XX w. kobiety w USA zarabiały średnio dwie trzecie tego, co mężczyźni ${ }^{43}$. W odpowiedzi na taka sytuację organizacja postulowała uruchomienie państwowego programu zapewniajacego pełne zatrudnienie kobiet oraz gwarantującego im odpowiednie warunki pracy.

Kwestia płac, a w szczególności postulat równej płacy za pracę o tej samej wartości, była drugim ważnym elementem programu CAW. Aby wyrównać płace kobiet i mężczyzn pracujących na tych samych stanowiskach, Kongres domagał się wpisania powyższej zasady do prawa krajowego, praw na poziomie stanowym i federalnym oraz do regulaminów zwiąków zawodowych. Dodatkowo organizacja wskazywała na konieczność zapewnienia możliwości zrzeszania się kobiet w ramach związów zawodowych w przedsiębiorstwach prywatnych i publicznych, ustalenia płacy minimalnej, wprowadzenia formalnego zakazu dyskrymi-

42 Ruth Benedict, Gene Weltfish, The Races of Mankind, (New York : Public Affairs Committee, 1943).

${ }_{43}$ Susan B. Anthony $2^{\text {nd }}$, Raport on the Status of Women, (New York : Congress of American Women, 1947), 2. 
nacji ze względu na płeć w zatrudnieniu oraz uruchomienia rządowego programu szkoleń zawodowych dla kobiet ${ }^{44}$.

Obok zatrudnienia inna fundamentalna kwestia podnoszona przez Kongres Kobiet Amerykańskich była praca domowa kobiet. Women's work is never done - to słynne powiedzenie stało się punktem wyjścia analizy sytuacji kobiet, które podlegały podwójnemu obciażeniu obowiazkami zawodowymi i praca domowa. Jak obliczała autorka raportu Susan B. Anthony (Druga), w 1946 r. w Stanach Zjednoczonych 28 milionów kobiet pracowało jako housewives, wykonując nieodpłatna pracę domowa. Aby zmniejszyć to obciążenie, Kongres proponował wprowadzenie krótszego dnia pracy zarówno dla kobiet, jak i mężczyzn. Zdaniem autorek takie rozwiązanie miało spowodować wyrównanie czasu poświęconego obowiązkom domowym przez kobiety i mężczyzn, zwiększając jednocześnie ilość czasu przeznaczonego na działalność społeczną, polityczną i kulturowa, a także redystrybucję miejsc pracy - ograniczenie czasu pracy doprowadzić miało do większego zapotrzebowania na nowych pracowników i zmniejszenia bezrobocia.

Podobnie jak aktywistki w Polsce działaczki Kongresu opowiadały się za równiejszym podziałem obowiązów domowych między kobietami i mężczyznami. W sferze postulatów Kongres Kobiet Amerykańskich proponował rozwiązania systemowe przenoszące ciężar odpowiedzialności za pracę domowa $z$ indywidualnych gospodarstw domowych na państwo. Pod wieloma względami te metody, istniejące $\mathrm{w}$ tym czasie w Zwiąku Radzieckim i wprowadzone po wojnie w krajach Europy Wschodniej, w tym w Polsce, przypominały opisane wyżej rodzaje polityki społecznej. Kongres domagał się zatem uruchomienia rządowego programu, którego celem byłoby stworzenie sieci komunalnych pralni, centrów opieki nad dziećmi, restauracji oraz izb chorych. Zdaniem członkiń Kongresu usługi te powinny być zawsze częścia planowanych inwestycji budowlanych, a także stanowić usługi niskopłatne, dotowane przez państwo. Członkinie CAW były zdania, że również obowiazzek zorganizowania opieki nad dziećmi powinien spoczywać na instytucjach państwowych. Domagały się zatem, aby państwo wzięło na siebie zadanie stworzenia sieci publicznych ogólnodostępnych centrów opieki nad dziećmi poniżej 5. roku życia oraz zagwarantowało możliwość nabycia tanich posiłków do spożywania w domu lub sieci kafeterii i stołówek w miejscach pracy i placówkach

44 Ibidem, 3-5. 
opiekuńczych (szkołach, przedszkolach). Postulowały też stworzenie systemu szkoleń zawodowych dla personelu tych placówek opłacanych przez państwo ${ }^{45}$.

Aktywizacja polityczna zajmowała ważne miejsce w działaniach na rzecz równości rekomendowanych przez CAW. Jak wskazywano w raporcie Komisji do Spraw Statusu Kobiet, po 1920 r. ruch kobiecy w USA był w odwrocie, a wcześniejsza działalność polityczna kobiet w znacznym stopniu przekształciła się w aktywności społeczno-kulturowe: kobiety zrzeszały się w klubach i grupach towarzyskich, lecz nie w organizacjach społecznych, partiach politycznych czy zwiazkach zawodowych. Odpowiedzią na bierność polityczną kobiet miała się stać prowadzona m.in. przez CAW działalność na rzecz włączania kobiet do działań politycznych, zarówno jako wyborczyń, jak i czynnych uczestniczek życia politycznego. Celem Kongresu było uświadamianie kobiet jako posiadających głos obywatelek, a także stworzenie możliwości zaangażowania politycznego $\mathrm{w}$ ramach istniejacych struktur politycznych, umożliwienie czynnego udziału w polityce, m.in. jako kandydatki na stanowiska wybieralne. Zarówno w swoich publikacjach, jak i w ramach organizowanych spotkań czy konferencji Kongres wspierał i promował kobiety kandydujące na stanowiska samorzadowe ${ }^{46}$.

\section{Transformacja przełomu lat 40. i 50. XX w.}

W powojennej Polsce okres stalinizmu, czyli lata 1948-1952, to czas intensyfikacji obecności kobiet na rynku pracy, tj. produktywizacji. Równość kobiet oraz zasady równej płacy za równa pracę zostały w tym czasie wpisane do Konstytucji uchwalonej 22 lipca 1952 r. Jednocześnie

\footnotetext{
45 Ibidem.

46 Jako organizacja jawnie propagująca poglądy progresywne, komunistyczne, antyrasistowskie, antykapitalistyczne i antyseksistowskie, pod koniec lat 40. Kongres Kobiet Amerykańskich znalazł się w gronie podmiotów podejrzanych przez władze antykomunistyczne o działalność wywrotową. W 1949 r. Amerykańska Komisja ds. Działalności Antyamerykańskiej (United States House Un-American Activities Committee, HUAC) ogłosiła raport na temat Kongresu, uznając Światowa Demokratyczną Federację Kobiet, której częścią był CAW, za agendę Związku Radzieckiego. Doprowadziło to do wyjścia Kongresu Kobiet Amerykańskich z Federacji, a w konsekwencji do rozwiązania CAW w 1950 r. Część członkiń Kongresu kontynuowała działalność polityczna, społeczną i naukową na rzecz równości kobiet, m.in. w takich organizacjach jak Women Strike for Peace. Część z nich współtworzyła ruch kobiecy drugiej fali, w ramach którego (prawdopodobnie w powodu doświadczonych represji) uniknęła jednak odniesień do swojej wcześniejszej działalności.
} 
już pod koniec lat 40. i na początku lat 50. XX stulecia w polskim ruchu kobiecym widoczna była tendencja do depolityzacji. Stanowiska traciły działaczki zasłużone dla rozwoju ruchu kobiecego, a liderki komunistyczne były przesuwane na mniej prominentne stanowiska partyjne i instytucjonalne, m.in. w ramach kampanii antysemickiej zapoczątkowanej jeszcze w okresie stalinowskim. W 1952 r. został zlikwidowany Wydział Kobiecy, a jego działania oceniono jako nieodpowiednie $z$ punktu widzenia potrzeb kobiet. W 1953 r. rozwiąano zakładowe komórki Ligi Kobiet, co było ważnym krokiem na drodze odpolitycznienia ruchu kobiecego, oddzielenia działalności organizacji kobiecych od miejsca pracy i ukierunkowania jej na miejsce zamieszkania.

Okres „odwilży” 1956 r. był z cała pewnościa przełomowy dla historii polskiego równouprawnienia, choć jego znaczenie nie jest jednoznaczne. Jak pokazuje w swojej książce Kobiety, komunizm i industrializacja $w$ powojennej Polsce Małgorzata Fidelis, czas destalinizacji miał ambiwalentne konsekwencje dla kobiet. „Z jednej strony zniesiono wszelkie formy przymusu w obszarze pracy zawodowej ... Kobiety, tak jak wszyscy obywatele, mogły swobodniej wyrażać własne poglądy, również w sprawie dyskryminacji w miejscu pracy i w sferze domowej ... Niektóre kobiety mogły odejść $z$ pracy na cały etat, by poświęcić się prowadzeniu domu, jeśli tego chciały, a warunki ekonomiczne nie stały na przeszkodzie"47. Olbrzymie znaczenie miały liberalizacja stalinowskiej ustawy antyaborcyjnej i poszerzenie dostępu do bezpiecznego zabiegu. W $1957 \mathrm{r}$. powstał Komitet Gospodarstwa Domowego, którego działania były nakierowane na zmodernizowanie i usprawnienie wcią̇ nieodpłatnej pracy kobiet w sferze prywatnej. Jednocześnie zapoczątkowane podczas „odwilży” reformy, odchodzace od „radykalnych” rozwiazań z poprzedniego okresu, umacniały przedkomunistyczną hierarchię $\mathrm{plci}^{48}$. Celem wprowadzanych od lat 50. XX w. regulacji dotyczacych urlopów macierzyńskich i opieki nad dziećmi było ułatwienie kobietom godzenia kariery zawodowej i rodzicielstwa. Rozmaite kursy, pokazy oraz szkolenia $z$ zakresu gospodarstwa domowego, głównej aktywności organizacji kobiecych w latach 60 . i 70., miały pomóc zarządzać czasem w sytuacji „podwójnego etatu”, gdy większość obowiązków domowych nadal spoczywała na ich barkach.

\footnotetext{
47 Małgorzata Fidelis, Kobiety, komunizm, 190-191.

48 Ibidem.
} 


\section{Zakończenie}

Celem niniejszego artykułu było wskazanie obszarów zainteresowań ruchu kobiecego po 1945 r. na podstawie dokumentów archiwalnych Wydziału Kobiecego PPR (a potem PZPR) oraz artykułów opublikowanych w wydawanym przez SOLK piśmie „Kobieta”. Moje analizy wskazują, że cele programu na rzecz równości kobiet w Polsce były zbieżne $z$ celami organizacji działajacych $w$ innych krajach, także zachodnich. Program wdrażany w Polsce był zgodny z postulatami artykułowanymi np. przez Kongres Kobiet Amerykańskich w ramach kluczowego dokumentu programowego tej organizacji „Raportu na temat statusu kobiet” autorstwa Susan B. Anthony (Drugiej). Kwestie takie jak zatrudnienie kobiet, uspołecznienie prac domowych oraz upaństwowienie opieki nad dziećmi stanowiły centrum zainteresowania działaczek kobiecych w krajach „nowych demokracji” i kobiet aktywnych w „progresywnych” ruchach antyrasistowskich i komunistycznych działających na Zachodzie, w tym w Stanach Zjednoczonych. Ważna, a właściwie kluczową rolę w wizjach równości kobiet artykułowanych w tym okresie zarówno w Europie Wschodniej, jak i USA odgrywało państwo - podmiot promowania i wdrażania równości. Jednocześnie działania na rzecz równości kobiet w Polsce oraz emancypacyjne w USA kładły nacisk na współpracę międzynarodowa. Wymiana doświadczeń i wiedzy na temat sytuacji kobiet $\mathrm{w}$ innych częściach świata była jednym $\mathrm{z}$ kluczowych punktów programu progresywnych ruchów kobiecych.

\section{Bibliografia}

\section{Źródła:}

AAN (1946-1948). Wydział Kobiecy PPR, sytuacja i zatrudnienie kobiet w Polsce - protokoły, sprawozdania, okólniki, instrukcje, uchwały, opracowania, korespondencja, sygn. 295/XVI.

Anthony, Susan B. Report on the Status of Women, (New York : Congress of American Women, 1947).

Biblioteka Sejmowa, sygn. 000020236, Deklaracja ideowa Społeczno-Obywatelskiej Ligi Kobiet, 1947.

Glińska, Elżbieta. „O rozwodach”, Kobieta, nr 10, 1948, 17. 
Gumowska, Irena. „Instytut Gospodarstwa Domowego”, Kobieta, nr 4, 1948, 21.

„Jesteśmy wszędzie”, Kobieta, nr 10, 1948, 6-7.

Krzywicka, Irena. „Nowy matriarchat”, Kobieta, nr 17, 1948, 18.

„Listy do Stefanii”, Kobieta, nr 19, 1948, 12.

Łempicka, Wanda. „Praca domowa dziewczat”, Kobieta, nr 3, 1947, 6.

Melcer, Wanda. „Warszawa-Sidney”, Kobieta, nr 10, 1948, 7.

Orłowska, Edwarda. „Po co owijać w bawełnę”, Kobieta, nr 48, 1948, 7.

Orłowska, Edwarda. „Powiedzmy sobie otwarcie... czujemy się nieswojo w Lidze", Kobieta, nr 47, 1948, 4.

Orłowska, Edwarda. „Tam gdzie dyrektorem jest kobieta”, Kobieta, nr 10, 1948, 7.

Staniszkis, Maria. „Ochrona pracy kobiet”, Kobieta, nr 18, 1948, 3.

WIDF (Women's International Democratic Federation). Second Women's International Congress. Account of the Work of the Congress Which Took Place in Budapest (Hungary) from the 1st to the 6th of December 1948, (Paris : Women International Democratic Federation, 1948).

WIDF. World Congress of Women. Reports, Speeches (Extract.) Documents, (Women's Berlin : International Democratic Federation, 1953).

\section{Opracowania:}

Benedict, Ruth, Weltfish, Gene. The Races of Mankind, (New York : Public Affairs Committee, 1943). ISBN 9780820356785.

Castledine, Jacqueline. Cold War Progressives. Women's Interracial Organizing for Peace and Freedom, (Urbana-Chicago : University of Illinois Press, 2012). ISBN 9780252094439.

Fidelis, Małgorzata. Kobiety, komunizm $i$ industrializacja $w$ powojennej Polsce, (Warszawa : WAB, 2015). ISBN 9788328015326.

Ghodsee, Kristen. Red Hangover. Legacies of Twentieth-Century Communism, (Durham, New York : Duke University Press, 2017). ISBN 978-08223-6949-3.

Grabowska, Magdalena. Zerwana genealogia. Działalność społeczna i polityczna kobiet po 1945 r. a współczesny polski ruch kobiecy, (Warszawa : Wydawnictwo Naukowe Scholar, 2018). ISBN 978-83-7383-931-1. 
Haan, Francisca de. "Continuing Cold War Paradigms in the Western Historiography of Transnational Women's Organisations. The Case of the Women's International Democratic Federation (WIDF)", Women's History Review, t. 19, z. 4, 2010, 547-573. ISSN 1933-2882.

Haan, Francisca de. „The Global Left-Feminist 1960s. From Copenhagen to Moscow and New York", w: Chen Jian, Martin Klimke, Masha Kirasirova, Mary Nolan, Marilyn Young, Joanna Waley-Cohen (red.), The Routledge Handbook on the Global Sixties, (London : Routledge, 2018), 230-242. ISBN 9781138557321

Haan, Francisca de. „Ten Years After. Communism and Feminism Revisited", Aspasia. The International Yearbook of Central, Eastern, and Southeastern European Women's and Gender History, z. 10, 2016, 102-168. ISSN 1933-2882.

Horowitz, Daniel. Betty Friedan and the Making of "The Feminine Mystique". The American Left, the Cold War, and Modern Feminism, (Amherst : University of Massachusetts Press, 1998). ISBN 9781558492769.

Jarosz, Dariusz. „Idee, programy i realia: funkcje Ligi Kobiet w porządku instytucjonalnym Polski Ludowej (1945-1957)”, w: Agnieszka Janiak-Jasińska, Katarzyna Sierakowska, Andrzej Szwarc (red.), Działaczki społeczne, feministki, obywatelki. Samoorganizowanie się kobiet na ziemiach polskich po 1918 roku (na tle porównawczym), t. 2, (Warszawa : Neriton, 2009), 307-330. ISBN 978-83-7543-026-4.

Jarska, Natalia. Kobiety z marmuru. Robotnice w Polsce w latach 1945-1960, (Warszawa : Instytut Pamięci Narodowej, 2015). ISBN 978-83-7629-764-4. Lerner, Gerda. Fireweed. A Political Autobiography, (Philadelphia : Temple University Press, 2002). ISBN 9781592132362.

McDuffie, Erik S. Sojourning for Freedom. Black Women, American Communism, and the Making of Black Left Feminism, (Durham, N.C. : Duke University Press, 2011). ISBN 978-0822350507.

Mrozik, Agnieszka. „Wywołać z milczenia. Historia kobiet w PRL-u - kobiety w historii PRL-u", Teksty Drugie: teoria literatury, krytyka, interpretacja, t. 4, z. 130, 2011, 112-119. ISSN 0867-0633.

Nowak, Barbara. Serving women and the State. The League of Women in Communist Poland, (PhD thesis : Uniwersytet Ohio, 2004). [Dostęp: 29.11.2019]. Dostępny w World Wide Web: <https://bit.ly/2LWC6nT>. 
Nowak, Barbara. "Where do you think I learned how to style my own hair?" Gender and Everyday Lives of Women Activists in Poland's League of Women", w: Shana Penn, Jill Massino (red.), Gender Politics and Everyday Life in State Socialist Eastern and Central Europe, (New York : Palgrave Macmillan, 2009), 45-58. ISBN 978-0-230-10157-9.

Nowakowska-Wierzchoś, Anna. „Związałyśmy się z siłami demokratycznymi w Polsce" - program polityczny i wizja roli kobiet w "nowej Polsce" Związku Kobiet Polskich im. Marii Konopnickiej we Francji 1944-1950", w: Ewa Chabros, Agnieszka Klarman (red.), Kobiety „na zakręcie” 19331989, (Wrocław : Instytut Pamięci Narodowej, 2014), 220-251. ISBN 9788361631408.

Weigand, Kate. Red Feminism. American Communism and the Making of Women's Liberation. (Baltimore-London : Johns Hopkins University Press, 1948). ISBN 978-0801871115. 